\title{
STRONG ABROAD AND WEAK AT HOME
}

The English language was paraded - awesome statistics, warts and all across ten pages of U.S. News $\mathcal{E}$ World Report on 18 February 85, in a survey that began: "What the French call la langue du Coca-Cola now dominates the globe in a way that no other tongue has since ancient Latin reached civilization's farthest shores.'

In contrast to the statistics offered by David Crystal in ETl (which settled on about a billion varied users of the language), U.S. News says: 'Now with a total near 750 million, 1 of every 7 people in the world claims some knowledge of English.' Points raised in the survey include:

- $83 \%$ of French secondary school students study the language of Coca-Cola

- In the Soviet Union, more than half of the secondary school students do the same

- Burma's ruler Ne Win banned English in 1962 and only rescinded the ban in 1981, when 'his favorite daughter flunked an English test required for graduate study in Britain ... but an entire generation had lost out in the meantime.'

The report states that British

English is still winning over American English; where the British Council is spending $\$ 64$ million 'this year' on teaching the language abroad, the USIA (United States Information Agency) is only spending \$8 million; however, 'while clipped Oxford English has a certain snob appeal in Europe, American English is making inroads.'

It is only at home that things are less sanguine. The review states that a 'diluted' regime in U.S. schools has led to 'the rise of "Bonehead" English': remedial courses for high-school and college students. Lower educational standards, faulty methodology in teaching reading and spelling, bilingual education, television and the electronic revolution are all considered as reasons for this apparent failure of the dream of universal literacy. A Library of Congress report is also quoted as saying:

"We must face and defeat the twin menaces of illiteracy and aliteracy - the inability to read and the lack of will to read - if our citizens are to remain free and qualified to govern themselves.'

came fluent readers of Aymara while its current speakers did not.

A vividly neologistic banner raised at the Oval in London in the summer of 1984, when the West Indies cricket team beat the England team on its own ground. lgebraic code. 'By using this code as an interface, or bridge, in the computer, he claims to have developed the beginnings of a multilanguage translation system.'

Basically, the idea is that computers could learn the grammar of any language - however whimsical and ambiguous - through the mediation of algorithmic Aymará; the language is 'so compact and orderly, so well-conceived,' says Guzmán, 'you might think it was designed.' Aymará has no irregular verbs or gender problems, but works with strings of suffixes added to root words. Out of the 'dying language of 2.5 million mostly illiterate Indians', he has created, says Simons, a system that is slowly silencing the initial laughter of anthropologists and computer specialists alike. Wang Computers have invited Guzmán to the U.S. to demonstrate his approach, he has been published in Canada, and UNESCO has given him a small grant to pursue his work. 